\title{
Analisis Kelayakan Ekonomi Sistem Pertanian Terpadu Pada Zona Agroekosistem Lahan Kering Dataran Rendah
}

\author{
Economic Feasibility Analysis of Integrated Agricultural \\ Systems In the Lowland Dry Land Agroecosystem Zone
}

\author{
M Basri \\ Politeknik Pertanian Negeri Kupang \\ *E-mail: mbasripolitani@gmail.com
}

Naskah Diterima : 11 Desember 2019; Di-review : 18 Desember 2019; Dimuat: 30 Desember 2019

DOI :

Copyright OFLOBAMORA 2019

\begin{abstract}
This study aims to analyze the economic feasibility of integrated farming systems in lowland upland agroecosystem zones. The sampling method used in this study was simple random sampling with a sample of 32 farmers. Data collection techniques used in this study were observation techniques, interview techniques and literature search. Data analysis uses (1) revenue and revenue analysis and (2). Business feasibility analysis ( $R$ / $C$ Ratio). The results showed that the results of the economic feasibility analysis of integrated farming systems in lowland dry land agroecosystems in Fatukanutu village, Kupang district, with an average land area of $1 \mathrm{ha}$. The total cost needed is IDR 28,015,000, with total receipts received IDR 76,902,000, and an income of IDR 48,887,000 per planting season. With an R / C Ratio of 2.73.
\end{abstract}

Keywords : Economy; integrated agriculture; agroecosostem; dry land and lowlands.

Abstrak

Penelitian ini bertujuan untuk menganalisis kelayakan ekonomi sistem pertanian terpadu pada zona agroekosistem lahan kering dataran rendah. Metode penentuan sampel yang digunakan pada penelitian adalah simple random sampling dengan jumlah sampel 32 petani. Teknik pengumpulan data yang digunakan dalam penelitian ini adalah teknik observasi, teknik wawancara dan penelusuran kepustakaan. Analysis data menggunakan (1) analisis penerimaan dan pendapatan dan (2). Analysis kelayakan usaha (R/C Ratio). Hasil penelitian menunjukkan bahwa dari hasil analisis kelayakan ekonomi sistem pertanian terpadu pada agroekosistem lahan kering dataran rendah di desa Fatukanutu, kabupaten Kupang, dengan rata-rata luas lahan 1 ha. Total biaya yang dibutuhkan sebesar Rp 28.015.000,- dengan total penerimaan diterima sebesar Rp 76.902.000, dan pendapatan sebesar Rp 48.887.000 per musim tanam. Dengan nilai R/C Ratio sebesar 2.73.

Kata Kunci: Ekonomi; Pertanian terpadu; Agroekosostem; Lahan Kering dan Dataran Rendah.

\section{Pendahuluan}

Sektor pertanian masih memainkan peranan penting dalam pembangunan ekonomi di Indonesia walaupun sumbangannya secara sektoral pada ekonomi negara masih kalah dibanding sektor minyak dan gas. Namun demikian, selama kurun waktu 20 tahun terakhir ini sudah sangat nyata sumbangannya terutama dalam penyediaan pangan dan penyerapan tenaga kerja bagi sebagian besar penduduk (Ferry, 1989). Oleh karena itu, sungguh relevan bila sektor pertanian selalu memperolah perhatian pemerintah maupun masyarakat yang menggantungkan hidupnya pada sektor pertanian. 
Keberhasilan terbesar pemerintah Indonesia yang pernah diraih adalah swasembada beras pada tahun 1984, merupakan berkat suksesnya program peningkatan produksi pangan.

Potensi lahan pertanian di wilayah Timor bagian barat provinsi Nusa Tenggara Timur (NTT) masih sangat luas. Saat ini wilayah Timor Barat memiliki luas areal potensial untuk pengembangan pertanian mencapai 1.043.023 ha. Dari total luas lahan tersebut $95,95 \%$ atau 1.000 .825 ha adalah sesuai untuk usahatani lahan kering dan sisanya 4,21\% (42.198 ha) adalah lahan basah (BPS NTT, 2013). Memperhatikan potensi lahan tersebut, maka berbagai macam program pemerintah daerah pun telah banyak digulirkan untuk menjaga kestabilan pangan melalui peningkatkan produksi pangan dan pendapatan masyarakat tani pedesaan. Namun, program-program yang digulirkan pemerintah daerah tersebut, belum memberikan kontribusi yang signifikan dalam upaya mendukung ketahanan pangan. Hal ini mungkin disebabkan oleh dua faktor, yaitu faktor fisik dan non fisik. Faktor fisik yang dimaksud adalah faktor iklim terutama curah hujan dan faktor fisik tanah (topografi) yang menjadi penentu pola usahatani di lahan kering. Sedangkan faktor non fisik adalah desain kebijakan pembangunan pertanian daerah yang sampai saat ini sangat bias ke usahatani padi sawah. Terkait dengan hal itu, maka perhatian terhadap perkembangan pertanian pada agroekosistem lahan kering menjadi sangat kurang. Selain desain kebijakan, juga pola usahatani tradisional yang bersifat parsial atau terpisah antar jenis usahatani, menjadi penyebab rendahnya produktivitas usahatani lahan kering. Secara umum masyarakat petani di wilayah Timor bermata pencaharian sebagai petani dan peternak. Kedua jenis usahatani ini tidak dapat dipisahkan dalam sistem usahatani lahan kering.

Permasalahannya sistem usahatani bersifat parsial, yaitu usahatani tanaman pangan diusahakan secara terpisah dengan ternak dan unit lahan untuk pakan ternaknya. Dampaknya adalah usahatani lahan kering tidak efektif dan efisien, yang terlihat dari rendahnya produktivitas usahatani lahan kering. Oleh karena itu penelitian ini bertujuan menganalisis kelayakan ekonomi sistem pertanian terpadu pada zona agroekosistem lahan kering dataran rendah.

\section{Kerangka Teori}

Integrated Farming System atau system pertanian terpadu sesungguhnya telah mengakar pada pertanian rakyat sejak lama dan menjadi bagian dari budaya bertani yang dijalankan oleh petani di wilayah Timor. Dalam system usahatani konvensional, ternak merupakan unsur penunjang yang diperlukan sebagai tabungan. Distorsi terhadap sistem konvensional mulai terjadi seiring dengan meningkatnya populasi penduduk dan menyempitnya lahan pertanian, serta meningkatnya budaya komersial (bisnis). Banyak lahan-lahan pertanian khususnya agroekosistem lahan kering dewasa ini dikategorikan sebagai lahan sub optimum yang dicirikan oleh banyaknya faktor pembatas sehingga berdampak pada rendahnya produktivitas usahatani lahan kering. Salah satu cara untuk memberbaiki dan mengoptimalkan produktivitas lahan kering tersebut adalah melalui penerapan pola pertanian terpadu dengan mengitegrasikan tanaman dan ternak dalam sistem usahatani. Ternak dapat memperbaiki kualitas dan meningkatkan produktivitas lahan melalui intensifikasi daur ulang unsur hara dan energi.

Integrated farming system dengan konsep dasar mengkombinasikan pesises tanaman dan hewan (ternak dan ikan), juga terkait dengan keterpaduan dalam pengelolaan tanaman. Menurut Artaji (2011) pengelolaan usahatani dengan model intergrated farming system, adalah suatu model integrasi yang mencakup:

1. Integrated Crop Management (ICM) atau

Pengelolaan tanaman Terpadu (PTT). PTT adalah strategi pengelolaan tanaman yang ditujukan untuk meningkatkan produktivitas tanaman melalui penerapan komponen teknologi secara terpadu. Penerapan PTT didasarkan pada lima prinsip utama yaitu: Pertama, PTT merupakan pendekatan pengelolaan sumber daya tanaman, lahan, dan air secara terpadu. Kedua, PTT bersifat spesifik lokasi sehingga penerapan komponen teknologi tidak berlaku secara umum. Ketiga, berlandaskan hubungan sinergis antara dua atau lebih teknologi produksi. Keempat, PTT bersifat dinamis sehingga terus berkembang sesuai dengan kemajuan teknologi. Kelima, PTT bersifat partisipatif yang membuka ruang lebar bagi petani untuk memilih, mempratekkan, memberikan saran, dan menyampaikan pengetahuan yang dimilikinya kepada petani lain (Fagi dan Kartaatmaja, 2004).

2. Integrated Nutrient Management (INM) atau Pengelolaan Hara Terpadu,yaitu menyediakan hara yang sesuai dengan jumlah hara (neraca hara) yang dibutuhkan oleh setiap komoditas, sehingga tercipta kecukupan hara dalam jumlah yang tepat dan tanaman dapat berproduksi optimal. Menurut Singh, dkk. (2012), konsep dasar pengelolaam hara terpadu adalah untuk membatasi eksploitasi kesuburan tanah dan nutrisi tanaman yang tidak menguntungkan. Manajemen nutrisi dapat dilakukan melalui pemanfaatan pupuk mineral dan pupuk organik yang berimbang dan memanfaatkan sumber daya lainnya sebagai sumber pupuk, seperti pupuk kandang, kompos, pupuk hijau, pupuk hayati, inokilan rhizobium

3. Integrated Pest Management (IPM) atau Pengelolaan Hama Terpadu (PHT) yang lebih efektif dan ramah lingkungan seperti penggunaan pestisida nabati,perangkap, predator alami, 
organisme antagonis, dan usaha-usaha pencegahan serangan hama/penyakit.

4. Integrated Soil Moisture Management (IMM) atau Pengelolan Air Terpadu PAT) seperti peggunaan irigasi teknis atau teknologi yang lebih canggih lainnya dalam sistem vertigasi.

5. Integrated Livestock Management (ILM) atau Pengelolaan Ternak Terpadu. Untuk peternakan dan/atau sistem/pola pertanian terpadu di mana ada hubungan timbal-balik antara pertanian dan peternakan.

6. Integrated Waste Management (IWM) atau Pengelolaan Limbah Terpadu. Untuk peternakan dan/atau sistem/pola pertanian terpadu di mana siklus biologi (bio-cycle) dalam usaha budidaya yang tidak terputus dan pemanfaatan biomassa yang lebih efektif dan efisien (zero waste management).

Sistem pertanian terpadu adalah mengkombinasikan berbagai macam spesies tanaman dan hewan (ternak, ikan) dan penerapan beraneka ragam teknik untuk menciptakan kondisi yang cocok untuk melindungi lingkungan juga membantu petani untuk meningkatkan produktivitas lahan dan pendapatan melalui diversifikasi usaha tani. Konsep tersebut mengindikasikan bahwa system pertanian terpadu merupakan sistem pertanian yang selaras dengan kaidah alam. Yaitu mengupayakan suatu keseimbangan di alam dengan membangun suatu pola relasi yang saling menguntungkan dan berkelanjutan di antara setiap komponen ekosistem pertanian yang terlibat. Dengan meningkatkan keanekaragaman hayati dalam system maka akan terjadi relasi yang saling menguntungkan, melalui pemanfaatkan bahan-bahan limbah organik dalam sistem. Peningkatan kaenekaragaman hayati merupakan hal penting dalam menanggulangi hama penyakit, pengurangan resiko, sedangkan pemanfaatan limbah organik perlu untuk menciptakan keseimbangan siklus energi (terutama daur unsur hara) yang berkelanjutan, serta untuk kepentingan konservasi tanah dan air.

Pertanian dalam arti luas terdiri dari lima sub sektor, yaitu tanaman pangan, perkebunan, peternakan, perikanan, dan kehutanan. Apabila masing-masing sub sektor pertanian dikembangkan secara terpisah maka sisa tanaman, perikanan dan kotoran ternak menjadi limbah yang dapat menimbulkan masalah bagi lingkungan, dan penanganannya memerlukan biaya tinggi sehingga akan meningkatkan biaya produksi usaha pertanian.

Kathleen (2011) menyatakan bahwa pertanian terpadu tanaman-ternak memiliki keunggulan, yaitu: dapat memperbaiki kualitas tanah, meningkatkan hasil, menghasilkan pangan beragam, input energy lebih rendah, biaya produksi lebih murah, dan memperbaiki efisiensi penggunaan lahan, serta lingkungan lebih baik.
Manfaat keterpaduan antara tanaman-ternak dan tanaman-ikan dapat disintesis melalui: (1) aspek agronomi yaitu peningkatan kapasitas tanah untuk berproduksi; (2) aspek ekonomi yaitu diversifikasi produk; hasil dan kualitas yang lebih tinggi, serta menurunkan biaya; (3) aspek ekologi yaitu menurunkan serangan hama dan penggunaan pestisida, dan pengendalian erosi; dan (4) aspek sosial yaitu distribusi pendapatan lebih merata. Pertanian terpadu, menurut Tipraqsa et al., (2007) juga bisa menciptakan lapangan kerja baru di pedesaan sehingga urbanisasi berkurang

Pada musim hujan dikembangkan model mina-padi-ternak, dan pada musim kemarau minasayur-ternak terpadu. Ternak dan ikan diberi pakan dari rumput dan sisa tanaman yang difermentasi, limbah kotoran ternak di proses menjadi pupuk organik dan digunakan untuk pemupukan tanaman. Sisa air buangan kolam digunakan sebagai air irigasi di lahan sayuran. Dari model yang dibuat dihasilkan penggunaan air lebih efiensi, peningkatan jenis produk pertanian, produksi pertanian lebih mengarah pada produk organik, akhirnya meningkatkan ketahanan pangan dan meningkatkan kesejahteraan petani.

Lebih lanjut, Bagas et al., (2015) menyatakan beberapa keunggulan yang dapat dilihat dari Pengembangan Sistem Pertanian Terpadu adalah :

a.Pertanian yang mampu menjaga keseimbangan ekosistem di dalamnya sehingga aliran nutrisi dan energi berimbang.

b. Keseimbangan energi tersebut yang dapat menghasilkan produktivitas yang tinggi dan keberlanjutan produksi terjaga.

c. Input dari luar minimal bahkan tidak diperlukan karena adanya daur limbah diantara organisme penyusunnya

d. Biodiversitas meningkat apalagi dengan penggunaan sumber daya lokal.

e. Peningkatan fiksasi nitrogen, resistensi tanaman terhadap jasad pengganggu lebih tinggi, dan hasil samping bahan bakar biogas untuk rumah tangga.

Athirah (2015) menyatakan pertanian terpadu secara deduktif akan meningkatkan efektifitas dan efisiensi produksi berupa peningkatan hasil produksi dan penurunan biaya produksi. Peningkatan hasil produksi karena semakin banyak hasil produksi yang diperoleh. Hasil-hasil dari sistem pertanian terpadu adalah hasil harian yaitu susu, telur dan biogas; hasil mingguan yaitu kompos, bio urine, pakan ternak; hasil bulanan yaitu padi, daging; hasil tahunan yaitu anak sapi, anak kambing, dll.

Itulah besarnya manfaat yang bisa diperoleh dengan penerapan sistem pertanian terpadu ini. Bahkan secara tidak langsung sistem ini akan meningkatkan kesehatan karena sumber energi pangan yang dihasilkan adalah organik seperti beras 
organik, sayur organik, daging organik dll. Selain itu harga jual bahan pangan organik seperti yang kita ketahui harganya dipasaran saat ini cukup fantastis sehingga hal ini bisa meningkatkan pendapatan para pelaku (Petani). Yang tak kalah penting, sistem ini juga berperan serta dalam pemeliharaan kuaalitas tanah yang kian hari keadaannya kian kritis. Tanaman membutuhkan unsur hara tanah dan C-organik yang cukup. Secara alami kebutuhan tersebut sudah tersedia di alam, namun ketersediaannya belum tentu mencukupi apalagi dengan pemakaian pupuk kimia dan pestisida yang berlebihan dan berlangsung sekian lama. Hal tersebut menyebabkan unsur hara dan C-organik dalam tanah tidak lagi tersedia seperti dulu. Hal ini merupakan tantangan bagi petani untuk mengembalikan dan meningkatkan kesuburan tanah secara berkelanjutan.

Dikatakan pula bahwa system pertanian terpadu memiliki keuntungan baik aspek ekologi maupun ekonomi. Keuntungan yang dimaksud, yaitu lebih adaptif terhadap perubahan (habitat lebih stabil), ramah lingkungan (UTARA/usaha tani ramah lingkungan), hemat energi (tidak ada energi yang terbuang), keanekaragaman hayati tinggi, lebih resisten, usaha lebih diversifikatif (risiko kegagalan relatif rendah), diversifikasi produk lebih tinggi, produk lebih sehat (minimalisasi residu senyawa berbahaya), keberlanjutan usaha tani lebih baik, serapan tenaga kerja lebih baik dan sinambung (Sutanto, 2002; Supangkat, 2009).

Integrasi tanaman pisang dan ternak sapi pada dasarya merupakan perpaduan dua komoditas yang bisa dikembangkan secara bersamaan pada unit lahan yang sama yang masing-masing komponennya saling membutuhkan satu sama lain. Tanaman pisang sebagai penghasil limbah pertanian bisa dimafaatkan sebagai pakan ternak. Semantara ternak sapi merupakan hewan ternak penghasil pupuk organik potensial yang dapat dimanfaatkan untuk memperbaiki dan meningkatkan kesuburan tanah. Dengan terpenuhinya salah satu input produksi terutama pakan untuk ternak sapi dan pupuk organic untuk tanaman pangan, maka kedua komponen dalam sistem tersebut diharapkan dapat menurunkan biaya produksi dan meningkatkan produksi. Dengan meningkatnya produktivitas lahan kering melalui penerapan sistem pertanian terpadu diharapkan dapat meningkatkan pendapatan dan kesejahteraan petani dan menguatnya ketahanan pangan petani di wilayah zona agro ekosistem lahan kering dataran rendah. Secara lengkap kerangka dasar pemkiran di kembangknnya model SPT pada zona agroekosistem lahan kering dataran rendah, dapat dilihat pada Gambar 1 .

Hasil Uji-coba model telah dilakukan pada zona agroekosistem dataran rendah berbasis pisang dan ternak. Tanaman menghasilkan biomasa yang dapat dijadikan sebagai pakan ternak. Sedangkan ternak menghasilkan pupuk kandang yang dapat dikembalikan ke lahan untuk memperbaiki dan mempertahankan kesuburan tanah. Interaksi tanaman dan ternak dalam model SPT berbasis tanaman pisang dan ternak sapi pada Zona Agro Ekosistem lahan kering dataran rendah. Secara umum lokasi penerapan model pertanian terpadu termasuk dalam zona dengan karakteristik lahan berada pada kemiringan $<15 \%$ dengan ketinggian tempat $<500 \mathrm{~m}$ dari permukaan laut. Lahan yang di uji-coba adalah lahan milik petani dengan luasan lahannya adalah 1 ha.

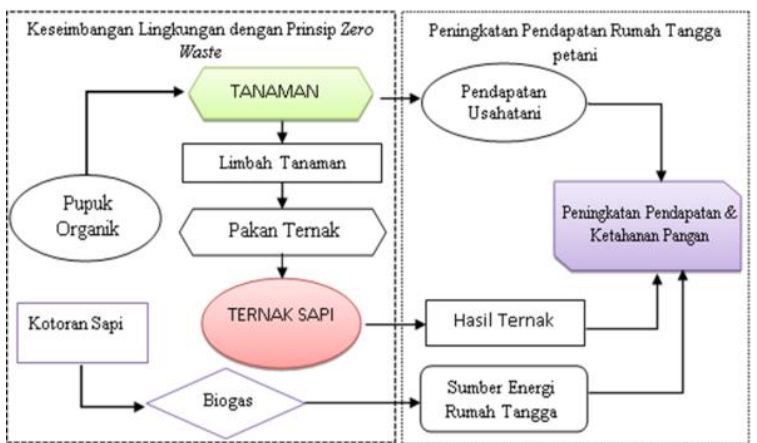

Gambar 1. Dasar pemikiran pentingnya penerapan integrasi tanaman dan ternak pada sistem pertanian terpadu dalam upaya meningkatkan produktifitas pada zona agro ekosistem lahan kering dataran rendah untuk peningkatan pendapatan dan kesejahteraan

Komponen penyusun dari model pertanian terpadu ini adalah tanaman utamanya adalah tanaman pisang, tanaman sisipan berupa tanaman pangan semusim (jagung dan sayur-sayuran), tanaman hijauan makanan ternak yang ditanam keliling kebun dan komponen ternaknya adalah ternak sapi dengan pola penggemukan yang dipelihara secara intensif (Gambar 2).

Secara rinci tahapan pengelolaan kebun adalah sebagai berikut: (1) Jenis tanaman pisang yang dikembangkan dalam model ini ada dua jenis yaitu pisang Beranga Kelimutu dan pisang kapok. Tanaman pisang sebagai tanaman utama ditanam dengan system mono raw, dengan jarak antar barisan adalah 20 meter dan dalam barisan adalah 6 meter., sehingga diperoleh populasi tanaman pisang sebayak 83 tanaman (Rumpun). Dalam pemeliharaan nya tanaman pisang diatur pertumbuhan anakannya, sehingga tiap rumpun hanya dipertahankan 3 anakan dengan umur yang berbeda (variasi umur \pm 4-5 bulan). Umur berbuah antara 8-9 bulan. Sehingga diperkirakan setiap tahunnya satu rumpun dapat dipanen 2 pohon secara benuntun, Limbah batang pisang dimanfaatkan sebagai pakan ternak sapi; (2) Di antara barisan tanaman pisang dimanfaatkan untuk usahatani intensif dengan mengembangkan berbagai tanaman pangan semusim, yaitu jagung manis atau jagung pulut (panen muda). Tanaman jagung sebagai tanaman sisipan dalam model dibagi 
dalam 4 blok. Jarak tanam jagung 1x0,5 m). Penanamannya diatur secara bertahap dengan interfal waktu tanam 2 minggu dengan tujuan untuk menjaga kesinambungan ketersediaan pakan ternak sapi. (3) Selain tanaman jagung, juga di dalam jalur tanaman pisang dapat ditanami dengan tanaman sayur-sayuran yang memiliki nilai ekonomi tinggi seperti tomat, cabe, terung, dan sayuran lainnya. (4) selain limbah jagung dalam system, untuk mendukung ketersediaan pakan ternak, maka disekeliling lahan ditanamai tanaman lamtoro dan juga rumput kinggras, (5) di dalam unit lahan dibangun kandang sapi untuk kapasitas dua ekor ternak sapi yang dilengkapi dengan pengolahan limbah. Pemeliharaan ternak sapi dilakukan secara intensif dengan pemberian pakan berupa campuran Batang dan daun pisang, rumput raja + limbah jagung + pangkasan legume lamtoro, yang disediakan secara terus menerus. (6) pembuatan pupuk organic dari limbah ternak dilakukan secara berkala, yaitu tiga kali dalam setahun.

Penerapan model di lokasi desa Fatukanutu memperlihatkan andanya efisiensi dalam pemanfatan lahan, karena adanya keragaman jenis tanaman yang bernilai ekonomi. Selain itu, daya dukung lahan terhadap usaha pemeliharaan ternak sapi meningkat, melalui pemanfaatan limbah dari barangkasan tanaman jagung dan limbah batang pisang. Berdasarkan komoditi yang diusahakan dalam model pertanian terpadu, selain diperoleh hasil ekonomis dari tanaman pisang dan tanaman jagung, juga diperoleh limbah yang dijadikan sebagai pakan ternak sapi. (Matheus, R, 2017)

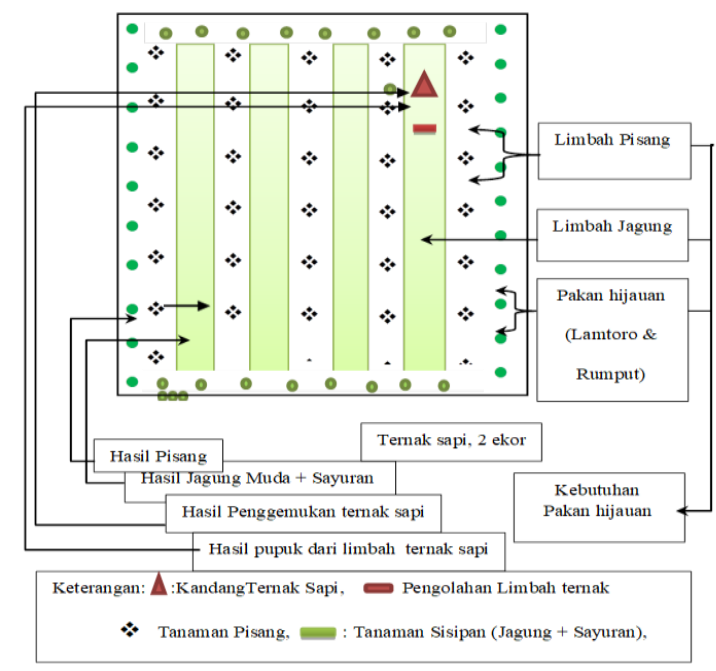

Gambar 2. Layout komponen penyusun dalam model Pertanian Terpadu berbasis pisang di zona dataran rendah.

Berdasarkan pengukuran lapang diperoleh data seperti berikut: Limbah tanaman jagung dari lahan seluas dalam satu tahun dengan dua kali tanam diperoleh brangkasan segar sebesar 7,5 ton/ tahun; hasil pangkasan rumput raja dalam lahan seluas 0,15 ha diperoleh pakan segar sebesar 10 ton/ tahun, serta pangkasan hijauan lamtoro sebanyak 1,2 ton/tahun, sehingga total pakan yang tersedia mencapai 18,7 ton/tahun. Rata-rata berat ternak sapi pada awal penggemukan adalah $185 \mathrm{~kg} /$ ekor. Jadi kebutuhan pakan segarnya selama masa penggemukan antara $50-60 \mathrm{~kg} / 2$ ekor/hari. Dengan melihat potensi limbah dalam SPT yang cukup banyak (18,7 t/tahun), maka hasil limbah seperti di atas dapat mencukupi kebutuhan 4 ekor ternak sapi/tahun. Namun demikian, dalam aplikasinya harus dilakukan secara bertahap: yaitu 2 ekor setiap 5-6 bulan pemeliharaan.

Berbagai hasil penelitian menyimpulkan bahawa, integrated farming system (system usahatani terpadu) mampu memperbaiki produktivitas usahatani. Sebagai contoh, produksi padi sawah di lahan petani, kalau biasanya hanya 5-6 ton/hektar dapat meningkat menjadi 7,6-8 ton/hektar (Agus, 2006). Produktivitas cabai besar dapat ditingkatkan dari $0,5 \mathrm{~kg} /$ tanaman menjadi 0,7 $\mathrm{kg} /$ tanaman (Nurcholis et al, 2010). Sistem pertanian terpadu akan lebih handal apabila komponen penyusunnya merupakan sumberdaya lokal sehingga keberlanjutannya lebih terjamin. Misal, komponen tanaman bersumber dari varietas lokal karena varietas ini lebih responsif terhadap lingkungan tumbuhnya sehingga tidak memerlukan masukan energi tinggi dari luar dan lebih tahan atau lebih mampu menyesuaikan terhadap perubahan lingkungan yang terjadi (fisik, kimia, hayati maupun ekonomi).Sedangkan, benih/bibit hibrida memiliki kelemahan, antara lain tidak mampu beradaptasi secara optimal dengan agroklimat lokal, menurunkan vigor dalam persilangan murni, seringkali benih hasil rekayasa tidak terbebas dari bibit hama dan penyakit dan menciptakan ketergantungan petani terhadap benih buatan pabrik setiap musim tanam (Goering, 1993 dalam Salikin, 2003). Sistem pertanian terpadu lebih familiar dengan kultur lokal mengingat sistem ini sebenarnya telah dikembangkan secara konvensional oleh petani Indonesia pada umumnya. Oleh karena itu, penerapan sistem ini secara kultural tidak mengalami hambatan. Secara umum, penerapan pertanian terpadu berbasis potensi lokal akan mampu menopang keberlanjutan pembangunan pertanian berkelanjutan baik pada tingkat mikro, meso (kabupaten/provinsi) mapun makro (nasional). Dampak positif penerapan sistem ini lebih dominan dibandingkan dampak negatifnya, baik ditinjau dari aspek ekonomi, sosial dan lingkungan karena sistem ini sejalan dengan konsep conserving while using (Suprodjo, 2009).

Sistem pertanian terpadu pada dasarnya merupakan respon petani terhadap factor resioko yang harus dihadapi, mengingat terdapatnya berbagai ketidak pastian dalam berusahatani (Soedjana, 2007). Pada saat persaingan dagang semakin meningkat dan issu pembangunan berkelanjutan menjadi perhatian, system pertanian terpadu perlu dikembangkan karena 
selain dapat menekan biaya pupuk pada tanaman dan menekan biaya pakan pada usaha ternak, juga dapat memperbaiki lahan yang rusak akibat penggunaan pupuk kimia yang berlebihan. Sistem pertanian yang demikian menurut Nurhidayati et al,. (2008) dikenal dengan system pertanian bekelanjutan dengan teknologi input luar rendah (Low External Input Sustainable Agriculture; LEISA)

\section{Metode}

Penelitian ini dilaksanakan di Kabupaten Kupang. Lokasi penelitian ini dipilih secara sengaja (purposive) dengan pertimbangan bahwa daerah tersebut merupakan daerah zona dataran rendah pada agroekosistem lahan kering. Penelitian ini dilaksanakan pada bulan April - November 2018. Populasi dalam penelitian ini adalah petani yang berusahatani tanaman pisang dan sayuran yang berjumlah 32 orang. Penentuan responden dilakukan secara sensus. Teknik pengumpulan data yang digunakan dalam penelitian ini adalah teknik observasi, teknik wawancara dan penelusuran kepustakaan. Data yang dianalisis dalam peneltian ini adalah data selama dua kali musim tanam, yang diperoleh dari hasil wawancara dan pengamatan langsung terhadap petani responden yang mengusahatanikan tanaman pisang di Desa Fatukanutu - Kabupaten Kupang.

Analisis data, dalam penelitian ini menggunakan dua bentuk analisis yaitu analisis pendapatan dan analisis Kelayakan Usaha sebagai berikut

pendapatan atau revenue usahatani pada agroekosistem lahan kering merupakan semua nilai produk yang dihasilkan dari suatu usahatani pada agroekosistem lahan kering dalam periode tertentu, satu musim tanam, atau dalam satu satuan kegiatan usaha. Analisis pendapatan pada agroekosistem lahan kering diperoleh dari perhitungan penerimaan dan biaya - biaya yang dikeluarkan dalam kegiatan usahatani.

Penghitungan penerimaan usahatani (sistem pertanian terpadu pada agroekosistem lahan kering) dilakukan menggunakan rumus :

$$
\mathrm{TR}=\mathrm{Q} \times \mathrm{P}
$$

Alat analisis yang digunakan selanjutnya adalah analisis imbangan penerimaan dan biaya ( $\mathrm{R} / \mathrm{C}$ ratio) . Penggunaan $\mathrm{R} / \mathrm{C}$ ratio bertujuan untuk mengetahui sejauh mana hasil yang diperoleh dari usaha menguntungkan dalam periode tertentu. $\mathrm{R} / \mathrm{C}$ ratio atas biaya total dilakukan menggunakan rumus :

$$
R / C \text { Ratio }=\frac{\text { Total Penerimaan }}{\text { Total Biaya }}
$$

Di Nusa Tenggara Timur, tanaman pangan semusim dan ternak sapi meupakan komoditas utama yang diusahakan pada usahatani lahan kering bagi hampir sebagian besar petani. Tanaman semusim (padi, palawija) berperan sebagai sumber pangan utama untuk menjaga ketahanan dan keamanan pangan (food safety \& security) dan ternak sapi berperan sebagai sumber sistem pendapatan (cash income), sehingga kedua komoditas (tanaman semusim dan ternak sapi) ini merupakan bagian yang tidak terpisahkan dari masyarakat Timor pada khususnya. Pertanian terpadu antara tanaman semusim dan ternak, merupakan salah satu model usahatani yang dapat meningkatkan produktifitas agroekosistem lahan kering, dan sangat cocok dikembangkan pada berbagai zona agroekosistem lahan kering. Untuk dapat memberikan gambaran terkait dengan kalayakan ekonomi dari model pertanian terpadu maka diperlukan analisis kelayakan model.

Selain itu, untuk dapat meningkatkan pendapatan usaha tani petani pada lahan kering adalah integrated farming system (system usahatani terpadu). Pengertian integrated farming system menurut Suwandi dalam Kariadi (2004) adalah suatu kegiatan petani dalam memanfaatkan secara optimal dan terpadu lebih dari satu komoditas pertanian, baik komponen usahatani pangan, palawija, hortikultura, ternak, dan ikan selama setahun pada unit lahan yang sama

Sistem pertanian terpadu yang dibangun harus dirancang untuk memenuhi kelayakan finansial dan skala komersialnya \{agar meneukupi kebutuhan nominal hidup layak petani pengelolanya). Oleh karena itu, untuk membangun sistem usaha tani yang tangguh ini pertama-tama perlu diketahui nilai nominal kebutuhan keluarga petani, misalnya per bulan. Selanjutnya perlu dipilih usaha tani yang secara finansial layak dilaksanakan, yang kemudian dengan membandingkan keuntungannya dengan nilal nominal kebutuhan hidup itu. Skala luasan lahan minimal perlu diketahui. Kebutuhan hidup yang layak adalah kebutuhan hidup sehat minimal dari suatu keluarga (tani) dalam bentuk nilai nominal yang setara dengan total nilal pangan, sandang, perumahan, pendidikan, kesehatan dan kebutuhan social lainnya, serta tabungan untuk jaminan hari tua. Batasan mengenai kebutuhan hidup yang layak tersebut dapat dipastikan sebagai standar hidup yang lebih tinggi daripada sekedar cukup pangan, sandang, dan perumahan sederhana, yang biasa disebut dengan kebutuhan hidup subsisten. Berbagai asumsi diperlukan untuk menetapkan skala komersial usaha tani terpilih yang dapat memenuhl kebutuhan hidup layak keluarga petani.

Asumsi-asumsi tersebut didekati dari faktorfaktor sebagai berikut:

\section{Hasil dan Pembahasan}


a. Jumlah anggota keluarga tani

b. Nilai nominal kebutuhan hidup bulanan yang harus dipenuhi

c. Adanya kemampuan produk bersaing di pasar d. Adanya kepastian pasar komoditi yang diusahakan Asumsi lain yang penting dalam konteks ini adalah bahwa petani telah memiliki rumah, tinggal memeliharanya atau merehabili-tasinya bilamana diperlukan.

Indicator kelayakan system pertanian terpadu dapat diukur dari kelayakan usaha, yang meliputi kelayakan teknis dan kelayakan ekonomi atau finansial. Kelayakan teknis atau efisiensi teknis berhubungan dengan jumlah maksimum output yang dapat dihasilkan dengan menggunakan input tertentu dan dengan penggunaan teknologi tertentu. Sedangkan kelayakan atau efisiensi ekonomi menggambarkan tentang keuntungan yang didapatkan setelah menerapkan model pertanian terpadu. Kelayakan ekonomi dapat diukur melalui analisis $\mathrm{R} / \mathrm{C}$ ratio, jika $\mathrm{R} / \mathrm{C}$ ratio bernilai lebih besar dari satu,layak dikembangkan karena memberikan keuntungan finansial.

Luas lahan minimum juga menentukan kelayakan usahatani . Luas lahan minimum merupakan luas lahan yang akan diusahakan dengan system pertanian terpadu, yang layak memenuhi kebutuhan hidup layak (KHL) untuk menghidupi suatu keleuarga dengan jumlah tanggungan yang berbeda. Penetapan luas lahan minimum didasarakan pada hasil analisis kebutuhan hidup layak (KHL) dibandingkan dengan pendapatan bersih (Ni).

Analisis usahatani pada zona agroekosistem lahan kering dataran rendah digunakan untuk mengetahui besarnya biaya yang dikeluarkan oleh petani dalam proses produksi, penerimaan yang diperoleh, dan pendapatan yang diperoleh petani dalam mengelola faktor-faktor produksi (input) yang ada. Untuk mengetahui besarnya pendapatan oleh petani pada zona agroekosistem lahan kering dataran rendah, maka terlebih dahulu harus mengetahui total dari penerimaan yang diperoleh, kemudian dikurangi dengan total biaya yang telah digunakan dari kegiatan usahatani yang dilakukan. Pendapatan dalam kegiatan usahatani dikatakan menguntungkan apabila penerimaan yang diperoleh lebih besar dari biaya yang dikeluarkan oleh petani. Dalam arti luas biaya adalah pengorbanan sumber ekonomi yang di ukur dalam satuan uang yang telah terjadi atau kemungkinan akan terjadi untuk mencapai tujuan tertentu (Mulyadi, 1993). Biaya dalam kegiatan usahatani dikeluarkan oleh petani dengan tujuan untuk menghasilkan pendapatan yang tinggi bagi usahatani yang dikerjakan. Dengan mengeluarkan biaya maka petani mengharapkan pendapatan yang setinggi-tingginya melalui peningkatan produksi.

Biaya produksi pada zona agroekosistem lahan kering dataran rendah adalah jumlah dari biaya tetap dan biaya variabel, dimana setiap kegiatan berusahatani tidak pernah terlepas dari biaya untuk mengelola usahatani agar memperoleh hasil yang diharapkan. Dalam struktur biaya produksi dapat dikategorikan dalam biaya tetap dan biaya variabel. Biaya tetap adalah biaya yang jumlahnya tidak berubah ketika kuantitas output berubah, sedangkan Biaya variabel adalah biaya yang besar kecilnya mempengaruhi kuantitas produksi.

Biaya tetap (Fixed Cost) Biaya yang relatif tetap jumlahnya dan harus dikeluarkan walaupun produk yang dihasilkan banyak atau sedikit. Biaya tidak tetap (Variable cost) Biaya tidak tetap yang sifatnya berubah-ubah tergantung dari besar kecilnya produksi yang dihasilkan. Dalam penelitian ini dikelompokkan ke dalam biaya tetap di antaranya adalah pajak dan sewa lahan, penyusutan alat, dan sewa traktor. Sedangkan untuk biaya variabel terdiri dari biaya benih, pupuk, pestisida, dan tenaga kerja.

Komponen biaya tetap Biaya tetap yang dianalisis oleh peneliti diantaranya meliputi biaya persiapan lahan/sewa traktor, biaya tenaga kerja dan biaya alat. Rincian besarnya komponen masingmasing biaya yang dikeluarkan dalam kegiatan usahatani pada zona agroekosistem lahan kering dataran rendah dapat di lihat pada tabel1 dibawah ini

Tabel 1. Komponen biaya tetap model sistem pertanian terpadu pada agroekosistem lahan kering dataran rendah.

\begin{tabular}{cllr}
\hline No & Komponen & Satuan & \multicolumn{1}{r}{ Jumlah } \\
\hline 1 & Persiapan Lahan & 1 Ha & $2,500,000$ \\
2 & Tenaga Kerja & 7 Org @ Rp 50.000x 14 hari & $4 . .900 .000$ \\
3 & Sperayer & 2 Unit & 800.000 \\
4 & Cngkul & 5 Unir @ Rp. 75.000,- & 375.000 \\
5 & Sabit & 5 Unit @ Rp. 35.000,- & 175.000 \\
6 & Garu & 5 Unit @ Rp. 40.000,- & 200.000 \\
\hline 7 & Kandang & 1 Unit & 5.000 .000 \\
\hline & Total & & 13.950 .000 \\
\hline
\end{tabular}

Biaya peralatan yang dihitung meliputi peralatan diantaranya terdiri atas cangkul, sabit, hand sprayer, dan garu. Sedangkan besarnya biaya peralatan yang dikeluarkan oleh petani baik dalam berusahatani pada sistem pertanian terpadu agroekosistem lahan kering dataran rendah dilihat pada table 1

Sewa traktor adalah salah satu komponen biaya tetap yang dikeluarkan oleh petani untuk keperluan kegiatan pengolahan lahan. Sebagian besar petani pada sistem pertanian terpadu agroekosistem lahan kering dataran rendah telah menggunakan traktor untuk pengolahan lahannya, Petani tersebut masih belum memiliki alat tersebut, sehingga petani menyewa traktor kepada petani lain maupun gapoktan. Namun ada juga beberapa petani yang masih menggunakan cangkul untuk kegiatan pengolahan lahannya.

Biaya irigasi adalah biaya yang dikeluarkan oleh petani untuk kebutuhan pengairan. Besarnya biaya irigasi tergantung pada luas lahan yang dimiliki 
petani, akan tetapi dari hasil pengamatan yang dilakukan oleh peneliti, Sedangkan pada zona agroekosistem dataran rendah terdapat penggunaan biaya irigasi dimana air yang diperoleh berasal dari air tanah dan difasilitasi oleh Gapoktan (Pengelolaan Pompa Air Tanah).

Penggunaan tenaga kerja sebagian besar petani dalam berusahatani pada zona agroekosistem lahan kering dataran rendah adalah berasal dari tenaga kerja di dalam keluarga, dan tenaga kerja besaral dari luar keluarga atau system ini sering disebut dengan borongan. Sistem pembayaran yang dilakukan dengan petani dengan cara pemberian upah harian. Upah tenaga kerja di lokasi penelitian ditetapkan sebesar Rp. 50.000,- per hari untuk tenaga kerja laki- laki maupun wanita biaya yang dikeluarkan oleh setiap petani pada tenaga kerja dalam usahatani

Upah tenaga kerja merupakan balas jasa yang diberikan kepada buruh tani atas kesediaannya membantu petani. Tidak semua petani pada zona agroekosistem lahan kering dataran rendah menggunakan tenaga kerja yang diupah, seperti dijelaskan diatas petani dalam melakukan usahatani terutama dalam pembersikan dan pengolahan lahan kebiasaan petani melakukan kegiatan secara bergotong royang dari satu lahan ke lahan yang lain, hal ini sudah merupakan tradisi turun- temurun sejak zaman dahulu. Sehingga budaya ini sampai dengan sekarang petani tetap dipertahankan, sehingga dapat mengurangi biaya yang dikeluarkan. Petani yang mengupah tenaga kerja biasanya membantu dalam menanam dan panen

Selanjutnya biaya variabel, dalam kegiatan usahatani pada zona agroekosistem lahan kering dataran rendah terdiri atas biaya benih, pupuk, pestisida, dan tenaga kerja. Besarnya biaya variabel yang dikeluarkan oleh petani dalam berusahatani pada zona agroekosistem lahan kering dataran rendah adalah sebagai berikut.

Tabel 2. Komponen biaya tidak tetap model sistem pertanian terpadu pada agroekosistem lahan kering dataran rendah.

\begin{tabular}{cllr}
\hline No & Komponen & Satuan & Jumlah \\
\hline 1 & Ternak Sapi & 2 Ekor @ Rp.3.500.000 & 7.000 .000 \\
2 & Bibit Pisang & 83 Anakan x @ Rp. 15.000,- & $1,245,000$ \\
3 & Benih Jagung & 5 Bungkus @ Rp. 120.000,- & 600.000 \\
4 & Benih Tomat & 3 Bungkus @ Rp. 65.000 & 195.000 \\
5 & Benih Cabe & 3 Bungkus @ Rp. 65.000 & 195.000 \\
6 & Pupuk Bokashi & 3000 kg x 1.000 & $3.000,000$ \\
7 & Pupuk Urea & 150 kg @ Rp. 2.200 & 330.000 \\
8 & Obat- Obatan & 1 Paket & 1.500 .000 \\
\hline & & 14.065 .000 \\
\hline
\end{tabular}

Bibit merupakan bahan baku utama yang akan menghasilkan produksi, oleh karena itu bibit unggul sangat diperlukan untuk mendapatkan produksi yang tinggi. Bibit yang digunakan petani adalah bibit jenis dengan varietas berupa benih unggul dengan merek $\mathrm{K}-\mathrm{K}$ Cross untuk benih tomat dan cabe, sedangkan jenis pisang yang ditanam oleh petani pada sistem pertanian terpadu agroekosistem lahan kering dataran rendah adalah jenis pisang branga. Sedangkan untuk tanaman jagung Bibit yang digunakan petani adalah bibit jenis Bisi 2

Petani pada sistem pertanian terpadu agroekosistem lahan kering dataran rendah, menggunakan pupuk organik hasil dari limba kotoran ternak di dalam SPT dalam dua kali musim tanam, menggunakan pupuk organik dalam kegiatan usahataninya, tetapi petani pada umumnya masih dominan menggunakan pupuk bokasi, selain itu petani juga menggunakan pupuk urea.

Faktor penentu keberhasilan dalam kegiatan usahatani adalah agar petani mampu menghasilkan tanaman pangan dan holtikultura dengan kualitas baik dan tahan terhadap hama penyakit. Salah satu cara yang dilakukan oleh petani pada zona agroekosistem lahan kering dataran rendah adalah pengendalian hama penyakit dengan menggunakan pestisida nabati. Penggunaan pestisida nabati oleh petani pada pada zona agroekosistem lahan kering dataran rendah sudah menjadi kebiasaan dalam penanganan hama penyakit yang menyerang tanaman.

Dalam analisis kelayakan model sistem pertanian terpadu pada agroekosistem lahan kering istilah efesiensi berhubungan dengan cara yang paling produktif dalam memanfaatkan dan mengelola sumberdaya-sumberdaya yang ada. Kata efisiensi berasal dari bahsa latin effecere yang berarti menghasilkan, mengadakan, menjadikan. Efisiensi dapat dirumuskan menurut suatu pengertian tertentu yaitu memaksimalkan perbandingan antara hasil bersih yang nyata dengan pengorbanan yang dihasilkan. Suatu kegiatan usaha tani dapat dikatakan efisien apabila telah mencapai hasil yang maksimal. secara umum mengenal dua jenis efesiensi yaitu efesiensi teknis dan efesiensi ekonomi.

Analisis kelayakan ekonomi dilakukan di lokasi uji-coba model pertanian terapdu berbasis pisang, dilakukan pada tahun kedua, agar semua komponen penyusun dalam model sudah menghasilkan. Uji-coba model ini melibatkan satu kelompok tani di desa Fatukanutu kabupaten Kupang. Luas lahan yang uji-coba adalah seluas 1 Ha. Pilihan pisang sebagai basis komoditas utama, karena pisang sebagai tanaman tahunan bisa memberikan kontribusi secara terus menerus atau secara kontinyu. Dalam model ini ada empat komponen penyusun, yaitu: (1). Ternak, (2). Pisang, (3). Jagung, dan (4). Tanaman Holtikultura ( Tomat dan Cabe) yang ditanam dengan pola tumpang sari. Junlah ternak yang dimasukan dalam sistem, sebanyak: 2 ekor sapi bakalan untuk tujuan penggemukan, dan dipelihara secara intensif dalam kandang. Kebutuhan pakan ternak untuk tahun pertama baru sebagian yang terpenuhi dalam sistem, 
namun tahun kedua semuanya sudah terpanuhi dalam sistem.

Tanaman pisang, sebagai tanaman utama ditanam dengan jarak tanam antar barisan $20 \mathrm{~m}$ dan dalam barisan $6 \mathrm{~m}(20 \times 6 \mathrm{~m} 2)$, sehingga dalam 1 ha diperoleh populasi tanaman sebanyak 83 rumpun. Umur berbuah untuk tanaman pisang antara 8-10 bulan. Setiap rumpun tanaman pisang akan dipertahankan 3 tanaman per rumpun, sehingga diperkirakan setiap tahun ada dua pohon setiap rumpun yang berbuah. Jadi total sebanyak 166 tandan yang bisa di panen dengan masa panen yang berbeda-beda.

Desain berbasis pisang dan ternak sapi, karena potensi wilayah, untuk pengembangan komoditas pisang dan ternak sangat besar. Dukungan lainnya adalah kondisi ikim serta budaya masyarakat yang menjadikan tanaman pisang dan ternak sapi sebagai komoditas utama. Gambar 3 dibawah ini menyajikan model SPT berbasis pisang dan ternak.

Pertanian terpadu berbasis pisang dan ternak akan lebih handal apabila komponen penyusunnya merupakan sumberdaya lokal sehingga keberlanjutannya lebih terjamin. Misal, komponen tanaman dan ternak bersumber dari varietas lokal karena varietas ini lebih responsif terhadap lingkungan tumbuhnya sehingga tidak memerlukan masukan energi tinggi dari luar dan lebih tahan atau lebih mampu menyesuaikan terhadap perubahan lingkungan yang terjadi (fisik, kimia, hayati maupun ekonomi).

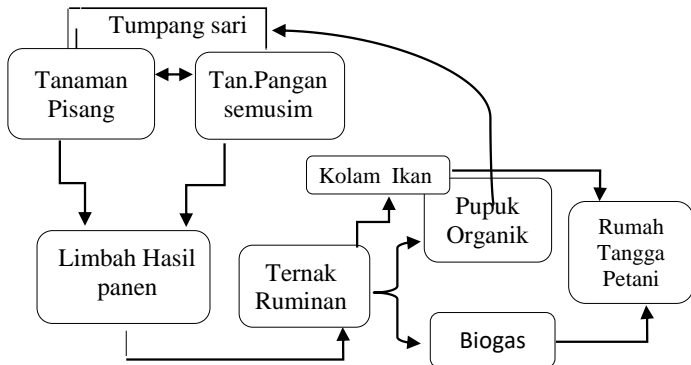

Gambar 3. Model Pertanian Terpadu berbasis Pisang dan Ternak Ruminansia

Model pertanian terpadu yang disajikan pada Gambar 3. tersusun dari tiga komponen penyusun, yaitu tanaman pisang dan ternak sebagai komponen utama dalam system, dan untuk memanfaatkan ruang kosong di antara tanaman pisang dilakukan pola tumpang sari dengan tanaman pangan semusim atau sayuran semusim. Dari keterpaduan tersebut di atas, dapat diperoleh berbagai keuntungan antara lain: adanya sumber pakan potensial yang berasal dari limbah dari batang pisang dan brangkasan/sisa hasil panen tanaman pangan, adanya input pupuk organik yang diolah dari limbah ternak, serta adanya sumber energy baru berupa biogas untuk memenuhi kebutuhan sumah tangga petani
Di antara barisan tanaman pisang dilakukan penanaman secara tumpang sari antara pisang-jagung dan pisang-sayur-sayuran. Jumlah jalur dalam areal tanaman pisang tersebut adalah 5 jalur, yang diatu pemanfaatannya: 3 jalur/loromg untuk tanaman jagung dan 2 jalur untuk tanaman sayur-sayuran, yaitu tomat dan cabe. Tanaman sisipan (jagung dan sayur-sayuran) ditanam dua kali dalam satu tahun. Jarak tanam jagung adalah $1 \mathrm{~m} \times 50 \mathrm{~cm}$, jarak tanam tomat adalah $40 \mathrm{~cm} \times 40 \mathrm{~cm}$, dan jarak tanam cabe adalah $80 \mathrm{~cm}$ x $40 \mathrm{~cm}$. Penentuan harga dalam analisis ini adalah harga yang beraku saat ini ditingkat petani. Sistem penjualan produk/hasil dari model adalah dengan cara pedangang membeli langsung di kebun petani. Berikut ini adalah komponen biaya yang dikeluarkan oleh petani dan pendapatan yang diterima oleh petani setelah mengembangkan model pertanian terpadu berbasis pisang dan ternak, (analisis dihitung pada tahun kedua penerapan).

Hasil analisis Tabel 3 menunjukkan bahwa usahatani terpadu berbasis pisang dan ternak sapi yang dikembangkan di zona agroekosistem dataran rendah, memberikan keuntungan sebesar Rp.48.887.000, atau setara dengan pendapatan bulanan sebesar Rp 4.073.000 per bulan, dengan nilai $\mathrm{R} / \mathrm{C}$ ratio sebesar 2.73. Nilai $\mathrm{R} / \mathrm{C}$ yang $>1$ ini menunjukkan bahwa usaha pertanian terpadu berbasis pisang layak untuk dikembangkan.

Suatu usahatani dikatakan efisien atau tidak efisien ditentukkan oleh besar kecilnya hasil yang diperoleh dan besar kecilnya biaya yang dikeluarkan untuk usahatani tersebut. kegiatan usahatani pada zona agroekosistem lahan kering dataran rendah dapat dilakukan dengan menghitung return cost ratio (Analisis RC), yaitu perbandingan antara total penerimaan dengan total biaya produksi. Berdasarkan hasil analisis $\mathrm{R} / \mathrm{C}$ ratio pada zona yaitu pada zona agroekosistem lahan kering dataran rendah diketahui bahwa nilai $\mathrm{R} / \mathrm{C}$ ratio lebih dari satu, Secara umum berdasarkan analisis R/C Ratio diketahui sistem usahatani pada zona agroekosistem lahan kering dataran rendah dinyatakan layak secara finansial

Penerimaan kegiatan usahatani tanaman pada zona yaitu pada zona agroekosistem lahan kering dataran rendah merupakan perkalian antara jumlah keseluruhan produksi yang dipanen. Jadi, besar kecilnya penerimaan ditentukan oleh besar kecilnya produksi dan harga jual (Daniel, 2002). Produksi usahatani tanaman dan ternak ratio pada zona yaitu pada zona agroekosistem lahan kering dataran rendah yang dihasilkan petani dalam berusahatani selama dua kali produksi berdasarkan luas lahan yang diusahakan. Seluas 1 ha yang terdiri dari tanaman dan ternak dapat dilihat pada tablel 3.

Analsis pendapatan/ keuntungan usahatani pada zona agroekosistem lahan kering dataran rendah digunakan untuk mengetahui besarnya pendapatan usahatani yang diperoleh oleh petani pada zona 
agroekosistem lahan kering dataran rendah . Untuk mengetahui besarnya pendapatan yang diperoleh petani, maka perlu diketahui terlebih dahulu besarnya tingkat penerimaan yang diperoleh serta biaya-biaya yang dikeluarkan dalam melakukan suatu usahatani tersebut. Pendapatan usahatani merupakan pengurangan biaya atau pengeluaran terhadap setiap hasil penjualan (penerimaan). Usahatani pada zona agroekosistem lahan kering dataran rendah bila dinilai dari tingkat pendapatannya merupakan selisih antara penerimaan dengan biaya yang dikeluarkan dalam usahatani tersebut. Dalam memperhitungkan pendapatan usahatani pada zona agroekosistem lahan kering dataran rendah terdapat tiga unsur perhitungan yaitu: pengeluaran usahatani, penerimaan usahatani dan pendapatan usahatani.

Pendapatan/ keuntungan yang diterima petani ini akan mengalami peningkatan pada tahun-tahun berikutnya, karena ada efisiensi atau penghematan komponen biaya pembelian pupuk sintesis. Biaya pengadaan pupuk dapat ditekan dengan penggunaan pupuk organik yang berasal dari pupuk organik yang dihasilkan dari kandang sapi yang ada dalam system

Efisiensi ekonomi dalam pengelolaan agroekosistem lahan kering dinyatakan bila sumber daya yang digunakan sebaik mungkin untuk memaksimumkan tujuan tertentu. Produktivitas berkenaan dengan kegiatan memproduksi output dengan efisien dan secara khusus merujuk ke relasi antara output dan input yang digunakan untuk memproduksi output. Total efisiensi produktif adalah suatu titik dimana dua kondisi dipenuhi untuk setiap campuran input yang akan memproduksi output tertentu, tidak diperlukan input berlebih dari yang dibutuhkan untuk menghasilkan output tersebut. Untuk mencapai efisiensi ekonomi dalam pengelolaan agroekosistem lahan kering agar lebih produktif, biaya produksi dalam pasar mestilah mencapai biaya produksi yang paling minimum. Kinerja efisiensi diukur dengan membandingkan antara output yang dihasilkan dengan input yang dipergunakan. Pada kinerja operasional, lazimnya output untuk proses produksi diukur dalam satuan unit produksi. Satuan ukuran sangat tergantung pada aktifitas yang diukur. Ukuran aktifitas penerimaan misalnya dapat diukur dengan banyaknya jumlah penerimaan. Tujuan pengukurannya adalah untuk meningkatkan produktifitas aktifitas penerimaan.

Menurut Soekartawi et al., (1995) pendapatan atau revenue usahatani pada agroekosistem lahan kering merupakan semua nilai produk yang dihasilkan dari suatu usahatani pada agroekosistem lahan kering dalam periode tertentu, satu musim tanam, atau dalam satu satuan kegiatan usaha. Analisis pendapatan pada agroekosistem lahan kering diperoleh dari perhitungan penerimaan dan biaya biaya yang dikeluarkan dalam kegiatan usahatani
Tabel 3. Hasil analisis eknomi usahatani pertanian terpadu berbasis pisang di Lokasi desa Fatukanutu, kabupaten Kupang.

\begin{tabular}{|c|c|c|c|c|}
\hline No & Uraian & \multicolumn{3}{|c|}{ SPT Berbasis Pisang dan Ternak Sapi } \\
\hline & $\begin{array}{l}\text { ZAE Dataran Rendah } \\
\text { Komponen Biaya }\end{array}$ & \multicolumn{2}{|l|}{ Fisik } & Rp \\
\hline A & & \multirow{2}{*}{\multicolumn{2}{|c|}{$1 \mathrm{Ha}$}} & \\
\hline 1 & Persiapan Lahan & & & $2,500,000,-$ \\
\hline 2 & Ternak Sapi & \multicolumn{2}{|c|}{2 Ekor@Rp.3.500.000 } & 7.000.000,- \\
\hline 3 & Bibit Pisang & \multirow{3}{*}{\multicolumn{2}{|c|}{$\begin{array}{l}83 \text { Anakan x @ Rp. 15.000,- } \\
5 \text { Bungkus @ Rp. 120.000,- } \\
3 \text { Bungkus @ Rp.65.000 }\end{array}$}} & $1,245,000$,- \\
\hline 4 & Benih Jagung & & & 600.000 \\
\hline 5 & Benih Tomat & & & $195.000,-$ \\
\hline 6 & Benih Cabe & \multicolumn{2}{|c|}{3 Bungkus @ Rp. 65.000} & 195.000,- \\
\hline 7 & Pupuk Bokashi & \multicolumn{2}{|c|}{$3000 \mathrm{~kg} \times 1.000$} & $3.000,000,-$ \\
\hline 8 & Pupuk Urea & \multicolumn{2}{|c|}{$150 \mathrm{~kg} @$ Rp. 2.200} & $330.000,-$ \\
\hline 9 & Obat- Obatan & \multicolumn{2}{|c|}{ 1 Paket } & 1.500 .000 ,- \\
\hline 10 & Tenaga Kerja & \multicolumn{2}{|c|}{7 Org @ Rp 50.000x 14 hari } & 4..900.000,- \\
\hline 11 & Pembuatan Kandang & \multicolumn{2}{|c|}{1 Unit } & $5.000 .000,-$ \\
\hline 12 & Sperayer & \multicolumn{2}{|c|}{2 Unit } & 800.000 \\
\hline 13 & Cngkul & \multicolumn{2}{|c|}{5 Unir@ Rp.75.000,- } & 375.000 ,- \\
\hline 14 & Sabit & \multirow{2}{*}{\multicolumn{2}{|c|}{$\begin{array}{l}5 \text { Unit @ Rp. 35.000,- } \\
5 \text { Unit @ Rp. 40.000,- }\end{array}$}} & 175.000 ,- \\
\hline \multirow[t]{2}{*}{15} & Garu & & & $200.000,-$ \\
\hline & Total Biaya & \multicolumn{2}{|c|}{5 Unit @ Rp. 40.000,- } & 28.015.000,- \\
\hline B & Penerimaan & Produksi & Harga & Jumlah \\
\hline 1 & Ternak Sapi & 2 Ekor & $7.500 .000,-$ & 15.000.000,- \\
\hline 2 & Pisang & 166 Tandan & $40.000,-$ & $6.640 .000,-$ \\
\hline 3 & Jagung & 23.040 Tongkol & $1.000,-$ & 23.040.000,- \\
\hline 4 & Tomat & $2.557 \mathrm{~kg}$ & $6.000,-$ & 15.342.000,- \\
\hline \multirow[t]{5}{*}{5} & Cabe & $2.110 \mathrm{~kg}$ & $8.000,-$ & 16.880.000,- \\
\hline & Total Penerimaan & & & 76.902.000,- \\
\hline & Keuntungan & & & 48.887.000,- \\
\hline & Pendapatan/bln & & & 4.073.917,- \\
\hline & Nilai R/C Ratio & & & $2,73,-$ \\
\hline
\end{tabular}

Menurut Soekartawi et al., (1995) pendapatan atau revenue usahatani pada agroekosistem lahan kering merupakan semua nilai produk yang dihasilkan dari suatu usahatani pada agroekosistem lahan kering dalam periode tertentu, satu musim tanam, atau dalam satu satuan kegiatan usaha. Analisis pendapatan pada agroekosistem lahan kering diperoleh dari perhitungan penerimaan dan biaya biaya yang dikeluarkan dalam kegiatan usahatani

\section{Kesimpulan}

Berdasarkan hasil analisis kelayakan usahatani terpadu berbasis tanaman pisang dan ternak sapi pada zona agroekosistem lahan kering dataran rendah dapat disimpulkan sebagai berikut: (1) Untuk dapat meningkatkan produktivitas dan pendapatan usahatani pada tanaman dan ternak harus melakukan diversifikasi usahatani baik vertikal maupun horizontal. Caranya dengan menerapkan pola usahatani terpadu sistem integrasi berbasis tanaman pisang dan ternak sapi. (2) Untuk dapat meningkatkan produktivitas agroekosistem lahan kering dan pendapatan usahatani harus melakukan perubahan pola usahatani dari pola konvensional (monokultur) menjadi pola pertanian terpadu dengan mengitegtasikan tanaman pisang, sayuran dan ternak sapi sesuai dengan potensi lokal; dan (3)Model sistem pertanian terpadu pada Agroekosisten dataran rendah diketahui bahwa.secara ekonomis menguntungkan karena Nilai $\mathrm{R} / \mathrm{C}$ ratio $>1$. 
Berdasarkan hasil kajian ini, maka disarankan agar perlu intervensi pemerintah dalam mensosialisasikan pengembangan sistem pertanian terpadu dengan focus pada komoditi pisang bagi petani sebagai upaya meningkatkan produktivitas usahatani lahan kering.

\section{Ucapan Terima Kasih}

Ucapan terima kasih disampaikan kepada Politeknik Pertanian Negeri Kupang (Kemenristek Dikti) selaku pemberi dana pelaksanaan kegiatan penelitian ini dan juga kepada semua pihak yang telah membantu penulis dalam menyelesaikan tulisan ini.

\section{Referensi}

Agus, 2006. Analisis Kelayakan Usahatani Padi Pada Sistem Pertanian Organik di Kabupaten Bantul [Jurnal]. Sekolah Tinggi Penyuluhan Pertanian Magelang, Yogyakarta

Artaji, W. 2011. Sistem Pertanian Terpadu - Model Pertanian Terpadu dalam Satu SiklusBiologi (Integrated Bio Cycle farming).http://ekonomikompasiana.com/agro bisnis/2011/10/12. [20 Desember 2011]

Athira. 2015. Sistem Pertanian Terpadu. https//athira09.wordpress.com/2011/10/15. Diakses tanggal 15 Oktober 2015

BPS NTT 2013. Nusa Tenggara Timur Dalam Angka.

Bagas,A; Tarmisi; Uthruva,T. 2015. Sistem Pertanian Terpadu. www academia.edu/8621874/Sistem pertanian terpadu

Fagi, A. M. dan Kartaatmadja. 2004. Evaluasi Pendahuluan Kelembagaan Sistem Usaha tani Tanaman-Ternak di Beberapa Kabupaten di Jawa Tengah dan Jawa Timur. Prosiding Lokakarya Sistem dan Kelembagaan Usaha tani Tanaman-Ternak. Badan LitbangPertanian.

Ferry, I. T. 1989. Swasembada pangan di Indonesia. Analisis CSIS, Tahun xviii No. 2

Kathleen, H. 2011. Integrated crop/livestock agriculture in the United States: A Review. J. Sustainable Agric. 35:376-393

Kariadi, I.K., I.M. Londra, FX. Loekito, dan I.G. Pastika. 2004. Laporan AkirPengkajian Sistim Usaha Tani Integrasi Ternak Sapi Potong dan Sayuran PadaFSZ Lahan Kering Dataran Tinggi Beriklim Basah. BPTP Bali.

Matheus, R.; Noldin. A. Bolla; M. Basri; Maria K. Salli; dan Antonius Jehemat, dan Rampon, M. 2017 Penerapan Sistem Pertanian Terpadu Sebagai Upaya Peningkatan Produktivitas Lahan Kering: Kajian pada dua zona agroekosistem lahan kering di Timor.
Proseding Seminar Nasional Politeknik Pertanian negeri Kupang ke-1, Kupang 7 September 2017, hal 16-26

Mulyadi, 1993, Akuntansi Biaya: Penentuan Harga Pokok dan Pengendalian Biaya, Edisi Kelima, Yogyakarta: BPFE UGM

Nurhidayati, I., Pujiwati, A., Solichan, Djuharu dan A. Basit. 2008. Pertanian Organik: Suatu Kajian Sistem Pertanian Terpadu Berkelanjutan. Program Studi Agroteknologi, Fakultas Pertanian Universitas Islam, Malang

Nurcholis, M. dan G. Supangkat., 2010. Pengembangan Integrated Farming System Untuk Pengendalian Alih Fungsi Lahan Pertanian. Prosiding Seminar Nasional BudidayaPertanian| Urgensi dan Strategi Pengendalian Alih Fungsi Lahan Pertanian | Bengkulu 7 Juli 2011 ISBN 978-602-192470-9

Salikin, K.A. 2003. Sistem Pertanian Berkelanjutan. Kanisius, Yogyakarta.

Singh, A.K., Manibhushan, M.K. Meena, and A. Upadhyaya. 2012. Effect of Sulphur and Zinc on Rice Performance and Nutrient Dynamics in Plants and Soil of Indo Gangetic Plains. Journal of Agricultural Science 4(11): 162170

Soedjana. 2007. Sistem Usaha Tani Terintegrasi Tanaman Ternak sebagai Respon Petani terhadap Faktor Resiko. WARTAZOA, 19 (3): 143-149.

Soekartawi, 1995. Analisis Usahatani. Penerbit Universitas Indonesia. Jakarta.

Supangkat, G. 2009. Sistem Usaha Tani Terpadu, Keunggulan dan Pengembangannya. Workshop Pengembangan Sistem Pertanian Terpadu. Dinas Pertanian Provinsi Daerah Istimewa Yogyakarta, tanggal 14 Desember 2009.

Suprodjo, S.W. 2009. Konservasi Ekosistem. Disampaikan pada Kuliah Perdana Program Studi Ilmu Lingkungan tanggal 21 Desember 2009, Fakultas Geografi UGM, Yogyakarta.

Tipraqsa, P., E.T. Craswell, A.D. Noble, D. SchmidtVogt. 2007. Resource integration for multiple benefits: Multifunctionality of integrated farming systems in Northeast Thailand. Agric. Sys. 94:694-703 